\title{
The New Case for Functional Separation in Wholesale Financial Services
}

Ingo Walter

\author{
Stern School of Business, New York University, New York, NY10012, USA
}

This version: 30 July 2009

\begin{abstract}
This paper reexamines the separation of commercial and investment banking in the context of modern wholesale financial environment, dominated by a small cohort of "systemic" institutions. The paper traces the pathology of regulation and deregulation from the watershed events of the 1930s to the systemic financial failures of the recent past. It then considers the structure, conduct and performance of the wholesale financial industry and how firms that cannot be allowed to collapse get that way. Based on the industrial organization of global wholesale finance, the paper then examines the available regulatory techniques, and makes some judgments as to their relative promise in promoting future financial stability with least possible dislocation of financial efficiency, proposing benchmarks for the calibration of proposals for regulatory reform. The paper then evaluates functional separation and carve-outs of high-risk activities that cannot defensibly be conducted within systemic financial firms in the real world of power politics and regulatory capture. The paper concludes that blanket condemnation of the functional-separation features of the 1930s financial reforms is unwarranted in the light of ongoing experience, and that it is time to revisit this issue in reconfiguring the global wholesale financial architecture.
\end{abstract}

Keywords: Financial regulation; Financial crisis; Glass-Steagall Act; Financial conglomerates; Universal banking, Financial sector reform; Financial architecture; Financial stability

JEL Classification: G20, G32, G34, G38, L13 


\title{
"When the facts change, I change my mind. What do you do, sir?"
}

\author{
- John Maynard Keynes, $1933^{1}$
}

\section{Introduction}

Future historians will doubtless come to see the 2007-09 global financial crisis as an economic and financial disaster of first magnitude, a perfect storm of macroeconomic policy, financial architecture, and regulatory fault-lines that pulled whole populations into its vortex, leaving behind individual and collective damage that will take years to remediate.

The only comparable crisis of this magnitude in modern times spanned the years 1929-33, triggered bu an equity market crash that wiped-out almost $90 \%$ of the DowJones Index in the US alone, followed by epic banking and economic collapse - one that today remains etched into the public consciousness. Then as now, there was understandable political pressure on governments to "do something." Then as now, there was no consensus on "what" should be done, beyond the immediate need to stop the bleeding and restore the lifeline utility functions of banking and financial intermediation. These have been classic examples of "learning by doing" on public policy, a process that cannot escape errors of judgment or second-guessing. But as the hurricane passes, as it always does, there soon comes a time to consider the longerterm future - earnest efforts to find ways of avoiding avoid comparable disasters going forward, and to prevent immediate damage-control initiatives from making the next one even worse.

Today as in the 1930s, the policy debates on how to repair a failed system center on regulatory reforms covering the key financial institutions and markets thought to be at the heart of the crisis. The reforms of the 1930s were as dramatic as they have been controversial in historical perspective. They doubtless extracted a cost in terms of economic and financial efficiency but produced critical gains in terms of financial stability and robustness - costs and benefits that are hard to calibrate given the inability to run the world twice. They certainly succeeded in creating a durable rules-based overlay for modern capital markets which persists more or less globally today. More controversially, they also set down barriers between commercial banking, and its public

\footnotetext{
${ }^{1}$ Reply to a criticism regarding a Keynes flip-flop on monetary policy, as quoted in Alfred L. Malabré, Lost Prophets: An Insider's History of the Modern Economists (Boston: Harvard Business School Press, 1994), p. 220
} 
utility characteristics, and what were then considered the far riskier activities comprising investment banking.

This functional separation of financial intermediaries, in the form of the GlassSteagall provisions of the Banking Act of 1933, came to be widely derided as unnecessary and ill-advised, and undoubtedly triggered unintended financial and economic consequences in the years that followed - some positive and some negative. Nonetheless, the Glass-Steagall provisions were associated with some 66 years of relative financial stability in what turned out to be an extremely turbulent world.

Today, less than a year after coming perilously close to a global financial meltdown, no meaningful financial system reforms have been agreed. Paradoxically, efforts to stem the short term bleeding have created even greater financial concentration, systemic risk exposure and moral hazard in global wholesale finance. And the more successful players are back to business as usual, with virtually no contrition and only cursory acknowledgment of those to whom they owe their survival, even as many of their erstwhile competitors remain wards of the state. The "animal spirits" of wholesale markets will not be tamed, nor should they be. Great zoos require great tigers, crocodiles and zebras. But they also require trained keepers, deep moats and high fences. In the real world of political influence-peddling and regulatory-capture - what Goldman Sachs CEO Lloyd Blankfein has called "our seventh line of business" ${ }^{2}$ - it is possible that the public interest can best be served by a coordinated global reinstatement of functional separation among financial intermediaries that create systemic risk.

This paper reexamines that separation in the context of modern wholesale financial environment, dominated as it is by a small number of "special" institutions whose failure can trigger global financial disaster. Section 2 of the paper traces the pathology of regulation and deregulation from the watershed events of the 1930s to the systemic failures of the recent past. Section 3 discusses the structure, conduct and performance of the wholesale financial industry and how firms that cannot be allowed to collapse get that way. Section 4 examines the available regulatory techniques and makes some judgments as to their relative promise in promoting future financial stability with least possible dislocation of financial efficiency. Section 5 evaluates functional separation and carve-outs of high-risk activities that cannot defensibly be conducted within systemic financial firms - running casinos inside public utilities - in the real world of power politics and regulatory capture. The paper concludes that blanket condemnation of the functional-separation aspect of the 1930s financial reforms is unwarranted in the light of ongoing experience, and that it is time to revisit this issue in reconfiguring the global wholesale financial architecture.

\footnotetext{
${ }^{2}$ New York Times, 18 July 2009 at http://www.nytimes.com/2009/07/19/business/19dimon.html?pagewanted=all
} 


\section{Legacies of the Past}

The so-called Glass-Steagall Act actually consists of four provisions of the Banking Act of 1933, arguably the most substantial piece of financial legislation to emerge from the Great Depression - legislation that also encompassed deposit insurance and other reforms designed to restore and maintain financial stability. One of its key provisions mandated a virtually complete separation of investment banking from deposit-taking activities. The Act thus eliminated involvement by firms with a commercial banking charter in the securities business - specifically, underwriting and dealing in corporate debt and equity securities and municipal revenue bonds (obligations not guaranteed by the full faith and credit of municipal governments). That business, which gained dramatically in volume during the 1920s, was dominated by an amalgam of universal banks such as JP Morgan and National City Corporation and broker-dealers banks such as Goldman Sachs and Lehman Brothers. The former were listed companies engaged in a full array of commercial and investment banking activities, and the latter were private partnerships engaged mainly in securities underwriting and trading, and investing their partners" capital.

Senator Carter Glass and other contemporary critics of the universal banking model feared that bank involvement in securities underwriting had directly and indirectly led them to ramp-up (warehouse) their holdings of long-term financial instruments, exposing themselves to potentially dangerous market, credit and liquidity risk. When this risk materialized with a vengeance, it was thought to have contaminated the entire US financial system by triggering the collapse of banks nationwide, which in turn had disastrous consequences for the real economy. About $40 \%$ of all US banks failed during this period, undermining their role as financial intermediaries and cutting off the air supply to the real economy.

The fact is that the big universal banks did increase their holdings of equities long-term debt securities during the 1920s, probably because the demand for short-term corporate loans declined substantially. But there is little evidence that the quality of bank securities holdings was responsible for the cascading bank failures of 1930-1933. Rather, the Federal Reserve System"s unwillingness to provide liquidity to a banking system beset by depositor runs was largely responsible for the banking collapse of the time. Under the circumstances that existed at the time, most of the banks that failed would have collapsed even if they had held no long-term bonds at all. [Walter, 1986] Evidence that commercial banks" securities activities somehow directly caused the Great Depression has remained elusive. The indirect causality, however, is a different matter.

Moreover, reevaluation of the historical events preceding passage of the Banking Act of 1933 suggest that the large universal banks of the time did not in fact exploit 
conflicts of interest that arose from their roles as commercial lenders and securities underwriters - for example using their privileged insight as lenders to prompt clients to issue securities and use the proceeds to repay commercial loans, thereby shifting losses from themselves to investors. The evidence? Securities underwritten by (potentially conflicted) universal banks did not underperform those underwritten by (nonconflicted) investment banks. ${ }^{3}$ And most of the financial abuses that did occur in the 1920s would have been effectively prevented by modern security markets regulation that itself was a product of contemporaneous financial reforms - the Securities act of 1933, the Securities and Exchange Act of 1934 and Investment Company Act of 1940. Most of the questionable transactions that appeared to have occurred between banks and their securities affiliates would have been deemed illegal under the financial laws and regulations tht followed. The emphasis of reformers in the 1930s was to prevent a recurrence of the situation rather than to seek retribution and punishment for those held to be responsible and they did what they did in good faith, under enormous pressure and in the "fog of war," where things that later became evident with the benefit of hindsight remained largely opaque.

The Glass-Steagall provisions of the Banking Act of 1933 forced the dissolution of the universal banks - for example the breakup of JP Morgan into the Morgan Bank (which in 1959 merged with the Guaranty Trust Company to form the Morgan Guaranty Trust Company of New York, the nation"s premier wholesale commercial bank) and what later became Morgan Stanley (of the nation"s top investment banks). Continental Europe, in contrast, engaged in no such functional separation and largely continued with the universal banking tradition, complemented by a few independent securities and advisory firms mainly in Italy (notably Mediobanca), France (the banques d"affaires) and the Netherlands. The UK went its own way with a commercial banking structure centered on a short list (determined by the Bank of England) of publicly listed clearing banks and a long tradition in the securities sector of "single capacity" jobbers (dealers), brokers and merchant banks, which was changed in Britain"s 1986 "Big Bang" reforms to allow the formation of broker-dealers, integrated investment banks and investment banking divisions of universal banks and financial conglomerates. In 1948 Japan was forced under the US occupation to adopt a version of the Glass-Steagall provisions in Article 65 of the Japan Securities and Exchange Law, which contained strict separation of commercial and investment banking.

Without access to the markets for deposits and commercial loans but protected from competition by commercial banks, US investment banks" share of financial intermediation grew rapidly as financial flows progressively shifted from the balance sheets of commercial banks and other credit institutions to the financial markets. They

${ }^{3}$ See for example Gande, Puri, Saunders and Walter [1997], Gande, Puri and Saunders [1999], Puri [1994] and Puri [1996]. 
in turn had a great deal to do with accelerating this process. Commercial paper markets, high-yield securities, asset securitizations, money market mutual funds and similar innovations were in part of product of investment banks" successful incursions into the credit institutions" market share, aided by the substantially lighter regulatory burdens they had to bear (notably capital requirements and liquidity requirements). By the 1980s the US had become heavily market-dominated while other financial systems remained universal bank-dominated, with the dominant banks heavily resistant to cannibalization of profitable business at home. This structural difference may have had something to do with a persistently higher US rate of economic growth during the 1980s and 1990s. The so-called Anglo-Saxon financial architecture was arguably more efficient, more disciplined and more innovative that the bank-dominated system. If true, then the GlassSteagall legislation may have paid handsome growth dividends for over half a century, dividends that might have been forgone if the US had persisted with a universal banking model after 1933.

Internationally as well, a consequence of Glass-Steagall may have been the progressive dominance of US investment banks in rapidly-evolving global capital markets. American broker-dealers, whose competitiveness was enhanced by the disappearance of fixed brokerage commissions in the SEC"s "Mayday" financial reforms in 1974, began a sustained offensive in foreign and offshore financial markets. Penetrating the fortresses of universal banking in one country after another, they mounted a sustained 20-year battle to wean European and later Asian corporates from their reliance on "Hausbank" relationships with universal banks, offering lower funding costs and innovative financings. Meanwhile, they cultivated the buy-side of the market, insurance companies, pension funds and other institutional investors, with new investment alternatives and ideas to improve portfolio efficiency. The offensive was so successful that virtually all the major universal banks in Europe mounted vigorous efforts to develop investment banking divisions of their own, but without having been battle-tested or having a viable footprint in the world"s largest securities market. By the early 1990s American investment banks basically dominated their industry worldwide, with a market share of about two-thirds - see Exhibit 1 for the market share data during 2004-05, two relatively normal years in global financial markets. And investment banking developed into one of the top US export industries - arguably another fortuitous consequence of Glass-Steagall. Had universal banking remained in place in the US after 1933, the lack of competitive pressure across very different strategic cohorts might well have involved significant opportunity costs.

Meantime, US wholesale commercial banks - notably Morgan Guaranty Trust Company, Bankers Trust, Chase Manhattan and Citicorp - began to agitate for reinstatement of universal banking powers to redress what they had come to regard as a debilitating competitive disadvantage. While they could and did compete vigorously in government bond, foreign exchange and other traded markets as well as corporate advisories, they were hamstrung in the "Glass-Steagall illegal" sectors of the market that were critical for competing in corporate finance. So the 1980 s saw a spate of political 
initiatives to get the rules changed. These included "high-road" arguments that the structure of financial intermediaries should be driven by competitive and strategic consideration, not anachronistic legislation. [Saunders and Walter, 1996] They also included "low road" initiatives such as Bankers Trust"s illegal underwriting of commercial paper in 1985, and then letting the courts decide the merits (Bankers Trust won).

By the late 1980s, commercial banks had gained the limited right to sell investment and insurance products to retail customers, as well as the right to operate separately capitalized, size-constrained wholesale securities subsidiaries (so-called Section 20 subsidiaries) under various safeguards to prevent the commercial banking from contamination by possible investment banking losses. This came in the form of administrative rulings on the part of the regulators, not legislative change. Perhaps a dozen of the major wholesale commercial banks took early advantage of this progressive liberalization to build significant securities subsidiaries, especially in the bond business, to complement their powerful wholesale commercial banking and government bond activities and their emerging presence in corporate advisory work. One key area in which the commercial banks made little headway was equities, a highly profitable growth market that was far removed from their traditional expertise in debt finance, and in which they had little sales and trading expertise and few natural relationships with companies undertaking IPOs. Moreover, lack of a market presence in equities seriously hampered their ability to build a competitive fee-based corporate finance business. This gap in their activity range lent even more urgency to removal of the remaining Glass-Steagall restrictions though legislative action.

With the political ducks lined-up for deregulation and the camel"s nose well under the tent through Section 20 subsidiaries, the merger in April 1998 of Citicorp and Travelers - illegal at the time but permitted under a two-year extendable grace period simply ignored the remaining functional barriers on the assumption that they would soon be lifted. This bold preemptive strike was soon validated by passage of the GrammLeach-Bliley Financial Services Modernization Act of 1999 (GLB), and itself may have accelerated the change in regulation.

Passage of GLB by an overwhelming Congressional vote of 343 to 86 put the final nail into the coffin of functional separation in US financial intermediation. At the retail level, it allowed commercial banks to gather assets into both bank deposits and securities accounts such as money market mutual funds, helping to stem the incursion by broker-dealers into their traditional client base and broadening their ability to respond to changes in client preferences. At the wholesale level, GLB allowed commercial banks to underwrite and trade in corporate debt, corporate equities and municipal revenue bonds and compete head-on with the broker-dealers. Together with repeal of the McFadden Act, which had limited interstate branching, with passage of the Riegel-Neal Interstate Banking and Branching Efficiency Act of 1994, the stage was set for a return 
to full-blown universal banking in the United States with few regulatory constraints on scale and scope in financial intermediation.

Among the remaining constraints, the 1999 deregulation did not remove the restrictions on banks under the Bank Holding Company Act of 1956 (BHC), which prevented financial institutions from owning non-financial corporations. It conversely prohibits corporations outside of the banking sector from entering deposit taking and commercial lending. This prompted many nonfinancial corporations such as General Electric and BMW to set up industrial loan corporations (ILCs), mainly chartered in Utah, which enabled them to take FDIC insured deposits and make commercial loans despite the BHC prohibition. It also allowed broker-dealers and investment banking units of financial conglomerates to set up FDIC-insured ILCs to offer their clients in the form of brokerage sweep accounts. Remaining in place was a cap of $10 \%$ on total US deposits booked by any single bank holding company, although the largest financial conglomerates soon lobbied for the cap to be be lifted - Bank of America, for example, argued that the cap makes U.S. banks vulnerable to foreign acquirers by limiting their ability to buy non-US banks that have significant domestic deposits. ${ }^{4}$

As in with the imposition of Glass-Steagall 66 years earlier, GLB"s sweeping functional separation had some dramatic if unintended consequences.

Within two years of deregulation, every major commercial bank that took full advantage of its new access to investment banking was involved in the most serious spate of corporate scandals of modern times - including the collapse of Enron and WorldCom - resulting in large losses for the banks themselves and their investor clients, major fines and legal settlements, and a general erosion of confidence in financial markets. Using their enormous balance sheets, the new financial conglomerates had become fee-chasing Goliaths that were played-off by rogue clients against each other and against the independent investment banks. As well, each was embroiled in major regulatory violations and exploitation of conflicts of interest, including corrupted equity research, facilitating late trading and market timing by hedge funds against the interests of ordinary shareholders of in-house mutual funds, and acting simultaneously as investor and intermediary in corporate actions.

Less than a decade after deregulation, these same financial conglomerates were at the center of the global financial crisis that began in 2007 as they chased after market share in the securitization business and aggressively followed along as the action increasingly involved dodgy credits ranging from sub-prime mortgages to leveraged loans. Besides encountering "pipeline" exposure to market, credit and liquidity risk in pursuit of a booming business, the financial conglomerates also took on "warehouse" exposure on their massive balance sheets or in off balance sheet conduits set up to avoid regulatory capital requirements. [Acharya and Richardson, 2009] Most would have failed in 2008 had they not by then become "systemic" institutions and

\footnotetext{
${ }^{4}$ Sybil White, "Riegle-Neal"s 10\% Nationwide Deposit Cap: Arbitrary and Unnecessary," http://studentorgs.law.unc.edu/documents/ncbank/volume9/cybilwhite.pdf
} 
beneficiaries of the largest corporate bailouts in US history, with massive socialization of the risks that they had assumed in executing their universal banking strategies.

The archetype of financial conglomerates and catalyst in accelerating reregulation, Citigroup, became the poster child for failed financial conglomerates, a death-star that virtually wiped-out its shareholders, dependent entirely on taxpayer lifesupport for its continued existence, and ultimately had to be partially nationalized with a 34\% government shareholding - see Exhibit 2.

\section{How Systemic Financial Firms Get that Way}

Industrial economics suggests that the structural form of competition between firms active in a given financial intermediation function, or in multiple functions should follow the dictates of institutional comparative advantage. If there are significant economies of scale, or economies of scope with respect to either costs or revenues, or if there are important linkages that can be exploited across geographies or client segments, we would expect to see the advantages reflected in, respectively, the size, the range of activities or the geographic scope or client breadth of those firms that are the most successful.

\section{A Simple Strategic Schematic}

Exhibit 3 depicts the market for financial services as a matrix of clients, products and geographies. [Walter, 2006] Financial firms clearly will want to allocate available financial, human and technological resources to those cells in the matrix (market segments) that promise to yield the highest risk-adjusted returns. In order to do this, they will have to attribute costs, returns and risks appropriately to specific cells in the matrix, and the cells themselves must be linked together in a way that recognizes and maximizes what both analysts and practitioners commonly call "synergies."

Client-driven linkages (horizontal arrows) exist when a financial institution can, as a result of serving a particular client or client-group, supply financial services more efficiently either to the same or another client in the same group in the same or different geographies. Risk-mitigation results from spreading exposures across clients, along with greater earnings stability to the extent that income streams from different clients or client-segments are not perfectly correlated.

Product-driven linkages (vertical arrows) exist when a firm can supply a particular financial service in a more competitive manner because it is already providing the same or a similar financial service in other client or geographic dimensions. Here again, there is risk mitigation to the extent that net revenue streams from different products are not perfectly correlated.

Geographic linkages (lateral arrows) are important when an institution can service a particular client or supply a particular service more efficiently in one geography as a result of having an active relationship with that client, or presence in that financial 
product, in another location. Once more, the risk profile of the firm may be improved where business is spread across different currencies, macroeconomic and interest-rate environments.

To extract maximum returns from the strategic positioning matrix, firms need to understand the size, growth and competitive dynamics of specific market segments, as well as the costs and the risks embedded in their overall portfolio of activities. Optimizing the linkages between the cells, in order to maximize potential joint cost and revenue economies, can be and especially challenging task. Firms that do this well can be considered to have a high degree of "strategic integrity" which should be reflected in a market capitalization that exceeds the stand-alone values of their constituent businesses. At the same time, exploiting the potential of the market matrix across revenue, cost and risk synergies engages the firm in higher levels of managerial complexity, conflicts of interest and other issues that could well be value-destroying.

The existence of large and complex "systemic" financial intermediaries suggests either that the benefits of size and complexity do in fact exceed their costs, that there are widespread failures in market discipline and effective corporate governance, or that size and complexity itself gives rise to an unpriced subsidy representing a transfer of wealth from society at large to the shareholders and employees of financial intermediaries.

\section{Economies and Diseconomies of Scale}

The question as to whether economies or diseconomies of scale exist in financial services has been at the heart of strategic and regulatory discussions about optimum firm size in the industry. Are larger firms associated with increased scale economies and hence profitability and shareholder value? Does increased average firm size create a more efficient financial sector? Answers are not easy to find, as it demands isolating the pure impact of size of the production unit as a whole from all the other revenue and cost impacts of size, as discussed below. In an information- and transactions-intensive industry such as financial services, which often has high fixed costs, there should be ample potential for scale economies. However, the potential for diseconomies of scale attributable to disproportionate increases in administrative overheads, management of complexity, agency problems and other cost factors can also occur in very large financial services firms. If the economies prevail, increased size will help create financial efficiency and shareholder value: if the diseconomies prevail, both will be destroyed.

Many studies of economies of scale have been undertaken in the banking, insurance and securities industries over the years. ${ }^{5}$ Unfortunately, examinations of both scale and scope economies in financial services are unusually problematic. The limited availability and conformity of data present serious empirical issues, and the conclusions of studies that have detected (or failed to detect) economies of scale and/or scope in a sample of financial institutions do not necessarily have general applicability.

\footnotetext{
${ }^{5}$ A. N. Berger and D. B. Humphrey, Measurement and efficiency issues in commercial banking, in Output measurement in the service sector, ed. Z. Griliches, Chicago, IL: University of Chicago Press (1992); I. Walter I. Mergers and Acquisitions in Banking and Finance. New York: Oxford University Press (2004).
} 
Nevertheless, the impact on the operating economics of financial firms is so important that available empirical evidence is central to the whole argument.

Cost estimation has uniformly found that economies of scale are achieved with increases in size among small commercial banks (below $\$ 100$ million in asset size). ${ }^{6} \mathrm{~A}$ few studies have shown that they may also exist in banks in the $\$ 100$ million to $\$ 5$ billion range. ${ }^{7}$ However, there is limited evidence to date of scale economies in the case of banks larger than $\$ 5$ billion, and although there has been some recent scattered evidence of scale-related cost gains for banks up to $\$ 25$ billion in asset size, ${ }^{8}$ there is none for very large banks (exceeding $\$ 25$ billion). Some studies have found the relationship between size and average costs to be U-shaped, suggesting that small banks can benefit from economies of scale as they grow bigger, but that large banks seem to suffer from diseconomies of scale and higher average costs due to factors like complexity as they increase in size.

The inability of empirical research to find significant economies of scale among large financial services firms is also true of the larger insurance companies and brokerdealers." The consensus seems to be that scale economies and diseconomies do not generally result in more than about $5 \%$ difference in unit costs. ${ }^{9}$ In fact, except for the very smallest banks and nonbank financial firms, firm-wide scale economies seem likely to have relatively little bearing on competitive performance. This is particularly true since smaller institutions are sometimes linked together in cooperatives or other structures that allow them to harvest any available economies of scale centrally, or are specialists in specific market-segments that are not particularly sensitive to such relatively small cost differences.

An underlying research problem is that most empirical studies focus entirely on firm-wide scale economies although the really important scale issues are encountered at the level of individual business units. There is ample evidence, for example, that economies of scale are significant for operational and competitive performance in areas such as global custody services, mass-market credit card transaction processing and institutional asset management. But they may be far less important in other areas, such as private banking and M\&A advisory services. Unfortunately, empirical data on cost functions that would allow researchers to identify economies of scale at the product level are generally proprietary, and thus unavailable. Still, it seems reasonable to argue that a scale-driven strategy may make a great deal of sense in specific areas of financial activity, even in the absence of evidence that there is very much to be gained at the firm-wide level. And since observations of firm-wide economies of scale are elusive, the notion that some lines of activity are likely to benefit from scale economies, suggests there must be other lines which suffer from diseconomies of scale.

\footnotetext{
${ }^{6} \mathrm{M}$. M. Cornett and H. Tehranian, Changes in corporate performance associated with bank acquisitions, Journal of Financial Economics, 31, 211-234 (1992).

${ }^{7}$ M. M. Cornett, G. Hovakimian, D. Palia and H. Tehranian, The impact of the manager-shareholder conflict on acquiring bank returns. Journal of Banking and Finance, 27 103-131(2003).

${ }^{8} \mathrm{~J}$. Houston and M. Ryngaert, The overall gains from large bank mergers, Journal of Banking and Finance, 18, 1155-1176. (1994).

${ }^{9}$ A. Saunders and I. Walter, Universal Banking in the United States, New York: Oxford University Press (1994).
} 


\section{Operating Efficiencies}

Quite apart from the conventional economies of scale and scope just discussed, financial firms of roughly the same size and providing roughly the same range of services (i.e., where scale and scope are identical) can in fact have very different cost levels per unit of output. There is ample evidence that such performance differences exist, for example, in comparisons of cost-to-income ratios among banks, insurance companies and investment firms of comparable size. The reasons involve differences in production functions, reflecting efficiency in the use of labor and capital, sourcing and application of available technology, and acquisition of inputs, organizational design, compensation and incentive systems - i.e., in just plain better or worse management.

A number of studies have found that disparities in cost structures among banks of similar size can be rather large, suggesting that the way banks are run is more important than their size or the selection of businesses they pursue. The consensus of studies conducted in the United States seems to be that average unit costs in the banking industry lie some $20 \%$ above those of "best practice" firms producing the same range and volume of services, and that most of the difference can be attributed to operating economies rather than to differences in the cost of funds. ${ }^{10}$ If true, this is good news for smaller firms, as it suggest that the quality of management is far more important in driving costs than raw size or scope. Of course, if very large institutions are larger because they have been systematically better managed than smaller ones (which may be difficult to document in the real world of financial services) there may indeed be a link between firm size and operating efficiency. The performance of various banks of different sized during the financial crisis of 2007-09 raises severe doubts about this proposition, however.

It is also possible that very large organizations may be more capable of making the massive and "lumpy" capital outlays required to install and maintain the most efficient information-technology and transactions-processing infrastructures. If such extremely high recurring technology spend-levels result in greater operating efficiency, large financial services firms will tend to benefit in competition with smaller ones. Smaller firms will then have to rely on pooling and outsourcing where this is feasible.

\section{Cost Economies of Scope}

Beyond pure scale-effects, are there cost reductions to be achieved by selling a broader rather than narrower range of products? Cost economies of scope mean that the joint production of two or more products or services is accomplished more cheaply than producing them separately. "Global" scope economies become evident on the cost side when the total cost of producing all products is less than producing them individually, while "activity-specific" economies reflect the joint cheaper production of particular pairs or clusters of financial services. Such economies can be harvested through the sharing of IT platforms and other overheads, lower information and monitoring costs and the like. Information, for example, can be reused and thereby avoid cost duplication, facilitate creativity in developing solutions to client needs, and

\footnotetext{
${ }^{10}$ A. N. Berger and D. B. Humphrey op cit 1.
} 
leverage client-specific knowledge.

On the other hand, cost diseconomies of scope may arise from such factors as the inertia and lack of responsiveness and creativity that may come with increased firm breadth, complexity and bureaucratization, as well as "turf" and profit-attribution conflicts that increase costs or erode product quality, or serious cultural differences between organizational "silos" that inhibit seamless delivery of a broad range of financial services.

Like economies of scale, cost-related scope economies should be directly observable in costs of financial services suppliers and in aggregate performance measures. But most empirical studies have failed to find significant cost-economies of scope in the banking, insurance or securities industries. ${ }^{11}$ They do suggest that some cost-diseconomies of scope are encountered when firms in the financial services sector add new product-ranges to their portfolios, finding that unit-costs seem to go up (although not dramatically) as product ranges widen. However, given the period covered by many of these studies, they tend to involve firms that were shifting away from a pure focus on banking or insurance, and that may therefore have incurred considerable frontend costs in expanding their activity range. Assuming these outlays affected firms" accounting statements during the sample period, one might expect to see this evidence of diseconomies of scope reversed in future periods.

\section{Revenue Economies of Scope}

On the revenue side, economies of scope attributable to cross-selling arise when the all-in cost to the buyer of multiple financial services from a single supplier is less than the cost of purchasing them from separate suppliers. This includes the cost of the services themselves plus information, search, monitoring, contracting and other costs. Firms that have diversified into several types of activities or geographic areas also tend to have more contact points with clients. As with the cost side, revenue diseconomies of scope could also arise from the management complexities and conflicts associated with greater breadth.

Historical studies have yielded some evidence on revenue economies of scope. Some studies have found that US bank affiliates typically underwrote better performing securities than specialized investment banks during the 1920s, when US commercial banks were permitted to have securities affiliates. Perhaps commercial banks obtained knowledge about firms contemplating selling securities through the deposit and borrowing history of the firm, which would enable them to select the best risks to bring to market. Other research has found that securities underwritten by commercial banks generated higher prices than similar securities underwritten by investment banks, which suggests the former carry lower ex ante risks. [Puri, 1994]

Most empirical studies of cross-selling are based on survey data, and are difficult

\footnotetext{
${ }^{11} \mathrm{G}$. DeLong, Stockholder gains from focusing versus diversifying bank mergers, Journal of Financial Economics, 59, 221-252 (2001); G. DeLong, Focusing versus diversifying bank mergers: Analysis of market reaction and long-term performance, Working Paper, CUNY (2001).
} 
to generalize. ${ }^{12}$ Regarding wholesale commercial and investment banking services, for example, one issue is whether companies are more likely to award M\&A work to banks that are also willing lenders, or whether the two services are separable - so that companies go to the firms with the perceived best M\&A capabilities (probably independent investment banking houses or boutiques) for advice and to others (presumably the major commercial banks) for loans. This is sometimes called "mixed bundling," meaning that the price of one service (e.g., commercial lending) is dependent on the client also taking another service (e.g., M\&A advice or securities underwriting). The search for immediate scope-driven revenue gains have led to some disastrous lending by commercial banks in the energy and telecoms sectors in recent years.

It is at the retail level that most revenue economies of scope are likely to materialize, since the search and contracting costs of retail customers are likely to be higher than those of corporate customers. The Glass-Steagall restraints in place until 1999 mean that there is only limited US evidence on retail cross-selling, and evidence from Europe (where universal banking has always been part of the landscape) is mainly case-based and suggests highly variable outcomes as to the efficacy of bancassurance or Allfinanz.

In any case, the future may see some very different retail business models, with clients taking advantage of user-friendly software interfaces to access Webservice platforms which allow real-time linkages to multiple financial services vendors. In effect, this will amount to "cross-purchasing" rather than "cross-selling", and give the client both the "feel" of single-source purchasing with access to best-in-class vendors. Apart from the continuous need for financial advice, such a business model could reduce information, transaction and contracting costs, while at the same time providing clientdriven open-architecture access to the universe of competing vendors. Advice could be built into the model, either by suppliers incorporating an advisory function into their downlinks, or through independent financial advisers. If such models of retail financial services delivery take hold in the market in the future, some of the rationale for crossselling and revenue economies of scope could become obsolete.

Despite an almost total lack of hard empirical evidence, revenue economies of scope may indeed exist at both the wholesale and retail level, but they are likely to be very specific to the types of services provided and the types of clients served. So revenue-related scope economies are clearly linked to a firm's specific strategic positioning across clients, products and geographies, as depicted in Figure 2. What little empirical evidence there is suggests that revenue-economies of scope seem to exist for specific combinations of products in the realm of commercial and investment banking, as well as insurance and asset management. ${ }^{13}$ But the proprietary nature of relevant incompany data has meant that no empirical studies have so far been available to confirm or refute the existence of revenue economies of scale at the individual product level.

\footnotetext{
${ }^{12}$ G. DeLong, ibid.; J. Houston, C. James and M. Ryngaert, Where do merger gains come from? Bank mergers from the perspective of insiders and outsiders, Journal of Financial Economics, 60, 285-331 (2001).

${ }^{13} \mathrm{~K}$. Mitchell and N. Onvural, Economies of scale and scope at large commercial banks, Journal of Money, Credit and Banking, 28, 178-199 (1996).
} 
Even if cross-selling potential exists, the devil is in the detail - mainly in the design of incentives and organizational structures to ensure that it actually occurs. These incentives have to be extremely granular and compatible with employee realworld behavior, or no amount of management pressure and exhortation to cross-sell is likely to succeed. Moreover, it seems likely that (given imperfect information) the broader a financial firm's activity-range (1) the greater will be the probability that it will encounter potential conflicts of interest, (2) the higher will be the potential agency costs facing clients, and (3) the more difficult and costly will be the internal and external safeguards necessary to prevent the exploitation of such conflicts of interest. If this is so, the competitive consequences associated with conflict-exploitation could offset the realization of economies of scope in financial services firms. The adverse legal, regulatory and reputational consequences of the exploitation such conflicts- along with the managerial and operational costs of complexity - point to the potential role of diseconomies of scope.

\section{Market Concentration and Leadership}

In addition to the strategic search for improved operating economies and revenue synergies, financial services firms will also seek to dominate markets in order to extract economic returns. This is often referred to economies of "size", as opposed to classic economies of "scale," and can convey distinct competitive advantages that are reflected in either business volume or margins, or both. Many national markets for financial services have shown a distinct tendency towards oligopoly, with market power allowing banks to charge more (monopoly benefits) or pay less (monopsony benefits). Supporters argue that high levels of market concentration are necessary in order to provide a viable competitive platform, while opponents argue that, without convincing evidence of scale economies or other size-related efficiency gains, monopolistic market structures serve mainly to extract rents from end-users of financial services and redistribute them to shareholders - or to cross-subsidize other areas of activity, invest in wasteful projects or reduce pressures for cost-containment.

Indeed, it is a puzzle why managers of financial services firms often seem to believe that the end-game in their industry's competitive structure is the emergence of a few firms in a competitive environment with high sustainable margins - for example US financial intermediation comprising 4 or 5 conglomerates with a combined market share of 60 or 70 percent. In the the real world, or course, such an outcome can easily trigger antitrust action leading to breaks-ups and spin-offs in order to restore more vigorous competition. Particularly in a critical - and thus highly politicized - economic sector such as financial services, a regulatory response to "excessive" concentration is a virtual certainty, despite the often furious lobbying in favor of greater concentration. In Canada, for example, regulators prevented two mega-mergers in late 1998 that would have reduced the number of major financial firms (all of them universal banks) from five to three, with a retail market share of about $90 \%$ between them. Regulators blocked the deals despite management arguments that US financial services firms operating in Canada under North American Free Trade Agreement (NAFTA) rules would provide the necessary competitive pressure to prevent the exploitation of monopoly power in the Canadian market. 
Despite very substantial consolidation in recent years (Exhibit 4) within that is perhaps the most globally concentrated financial services industry sector - wholesale banking and capital markets activities - there is little evidence of excessive market power. Although some $80 \%$ of the combined value of global fixed-income and equity underwriting, loan syndications and M\&A mandates is captured by the top-ten firms, the industry remains subject to ruthless competition in most of these business areas. Exhibit 5 shows why, using data from the first half of 2009 - Herfindahl-Hirshman ratio of only about $1,200(0<\mathrm{HHI}<10,000)$ due to the evenness of market share distribution among the top firms. This intense competition has been reflected in the returns to investors in shares of the principal players. There is some evidence that despite all the consolidation activity in global wholesale banking there has been a long-term erosion of returns to capital invested in this sector, encouraging the firms to focus increasingly into proprietary trading and principal investing and their attendant risks.

A similar situation exists in asset management, where the top firms comprise a mixture of European, American and Japanese fund managers, plus a variety of banks, broker-dealers, independent fund management companies and insurance companies. Although market definitions clearly have to be drawn more precisely, at least on a global level asset management seems to be among the most contested sectors in the financial industry, although it has shown very few signs of increasing concentration in recent years.

In short, although monopoly power created through mergers and acquisitions in the financial services industry can produce market conditions that allow firms to reallocate gains from clients to themselves, such conditions are not easy to achieve or to sustain. New players - even relatively small entrants - can penetrate the market and destroy oligopolistic pricing structures, and end-users are willing to shop around among good substitutes available from other types of financial services firms. Even after extensive consolidation in global wholesale banking, vigorous competition seems to have been maintained in most cases.

\section{Proprietary Information and Imbedded Human Capital}

One argument in favor of large, diverse financial services firms is that internal information flows are substantially better - and involve lower costs - than the external information flows available to more narrowly focused firms. Consequently a firm that is present in a broad range of financial markets, functions and geographies can find proprietary and client-driven trading and structuring opportunities that smaller and narrower firms cannot.

A second argument has to do with technical know-how. Significant areas of financial services - particularly wholesale banking and asset management - have become the realm of highly specialized expertise, which can be reflected in both market share and price effects. As noted, large numbers of financial boutiques have been acquired by major banks, insurance companies, securities firms and asset managers for precisely this purpose, and anecdotal evidence suggests that in many cases these acquisitions have been shareholder-value enhancing for the buyer. 
Closely aligned to this is the human capital argument. Technical skills and entrepreneurial behavior are embodied in people, and people can (and do) move between firms. Parts of the financial services industry have become notorious for the mobility of talent, sometimes to the point of "free-agency," with people or even teams of people regarding themselves as "firms within firms."

There are no empirical studies of these issues, although there is little question as to their importance. Many financial services are specialist businesses, conducted by specialists, to meet specialist client requirements. The know-how embodied in people is clearly mobile, and the key is to provide a platform that is sufficiently incentive compatible to make the most of it. But in terms of the wider arguments, it is unclear whether institutional size or breadth has much to do with this.

\section{Diversification, Financial Stability and Bankruptcy Risk}

Greater diversification of earnings attributable to multiple products, client-groups and geographies is often deemed to create more stable, safer, and ultimately more valuable financial institutions. The lower the correlations among the cash flows from the firm's various activities, the greater the benefits of diversification. The consequences should include higher credit quality and higher debt ratings (due to lower bankruptcy risk), and therefore lower costs of financing than those faced by narrower, more focused firms, while greater earnings stability should bolster stock prices. In combination, these effects should reduce the cost of capital and enhance profitability.

A number of empirical studies have attempted to assess the value of diversification in terms of earnings stability by back-testing the impact of hypothetical paired or clustered combinations of financial firms. What impact would the combination of various commercial banks, broker-dealers, insurers and asset management firms have had on earnings stability of the constituent firms, adjusting for the level of earnings? [Saunders and Walter, 1994]. The findings of such studies generally conclude that relatively low correlations among key financial businesses do indeed explain a positive stability-effect of firm scope.

\section{Conglomerate Discount}

It is often argued that, all else being equal, the shares of business conglomerates tend to trade at prices lower than shares of more narrowly-focused firms. There are two basic reasons why this "conglomerate discount" is alleged to exist.

First, it is argued that, on the whole, conglomerates tend to use capital inefficiently. This may be attributable to managerial discretion to engage in valuereducing projects, cross-subsidization of marginal or loss-making projects that drain resources from healthy businesses, misalignments in incentives between central and divisional managers, etc. Most erosion of value in conglomerates is blamed on overinvestment in marginally profitable activities and cross-subsidization. If it is true that conglomerates' internal capital markets function less efficiently than the external capital market, their shares ought to trade at a discount to the stand-alone value of their constituent businesses. [Berger and Ofek, 1995] 
The empirical findings based on research across broad ranges of nonfinancial businesses may well also apply to the diverse activities carried out by financial firms. If retail and wholesale banking, and P\&C insurance, are evolving into highly-specialized, performance-driven businesses, for example, one may ask whether the kinds of conglomerate discounts found in industrial firms may not also apply in the case of financial conglomerate structures - especially if centralized decision-making is becoming increasingly irrelevant to the requirements of the specific businesses.

A second possible source of conglomerate discount is that investors in shares of conglomerates find it difficult to "take a view" and will want to avoid such stocks, preferring to add pure sectoral exposures in their efforts to construct efficient assetallocation profiles. This is especially true where performance-driven managers of institutional equity portfolios are under pressure to outperform cohorts or equity indexes - why would such a fund manager want to invest in yet another (closed-end) fund in the form of a financial conglomerate, which might be active in retail and wholesale commercial banking, in middle-market lending, private banking, corporate finance, trading, investment banking, asset management insurance and perhaps other businesses as well?

Both the capital-misallocation and the portfolio-selection effects tend to weaken investors' demand for shares of universal banks and financial conglomerates, thus lowering their equity prices and leading to a higher cost of capital. In turn, this will have a bearing on the competitive performance and profitability of these financial giants, perhaps enough to wholly or partially offset some of the aforementioned benefits of conglomeration such as greater stability and lower bankruptcy risk through diversification across business lines.

Recent large-scale empirical studies have attempted to ascertain whether or not functional diversification in the financial services sector is value-enhancing or valuedestroying. One study [Schmid and Walter, 2009] based on a large U.S. dataset covering the period 1985-2004 found evidence of substantial and persistent conglomerate discounts among financial intermediaries, with the empirical results suggesting that it was diversification that caused the discounts, rather than the discounts resulting from troubled firms diversifying into other more promising areas. The study also investigated both the geographic dimension of diversification and the interaction between geographic scope and functional diversification, concluding that the value-destruction associated with functional diversification was not apparent with geographic diversification.

These results were broadly in line with those of another study that found strong evidence of a conglomerate discount in a sample of 836 banks from 43 different countries. [Laeven and Levine, 2007]. This coincidence of empirical findings was remarkable in that the panel data used in the two investigations were quite different; one focused on diversification among banks and the other considered diversification along all forms of financial intermediation.

\section{Mispriced Financial Support - Government Bailouts and Financial Conglomerates}


The preceding discussion has focused on the industrial economics of financial intermediation - scale, scope, market structure, operating efficiency, information and transaction costs, diversification, conglomerate discount and other fundamental drivers of size and scope. Is bigger better? Is broader better? It all depends on the underlying economics of the financial intermediation business, and the balance could cut either way. And even a dispassionate conclusion may be overridden by managements and boards if there are serious agency problems causing their objectives to differ from those of shareholders.

The gorilla in the room, however, is the prospect of government support under adverse circumstances - support that could totally distort the finely-honed microeconomics of financial intermediation. Financial services, as an industry, is arguably more likely to attract government support than any other. So it is no surprise that this contingent claim on the public purse may influence the behavior of equity and debt investors, clients and counterparties, depositors, managers and boards. If the taxpayer is going to hold a credible safety net, why not perform exciting, even deathdefying tricks far up on the high-wire?

While there is almost never a formal government bailout commitment to financial intermediaries, financial services firms that surpass a given size threshold (or are otherwise judged to be "systemic") will usually be bailed-out by taxpayers. Historically in the United States, this public support became explicit when the Comptroller of the Currency testified to Congress in the 1980s that 11 banks were so important that they would not be permitted to fail - bank bailouts were clearly undertaken in the savings and loan collapses during that decade in order to keep the rot from spreading to the financial system more broadly. The same policy tends to exist in other countries, and in most cases covers even more of the local financial system - there were numerous examples in France, Switzerland, Norway, Sweden, Finland, and Japan and most AsiaPacific countries during the1990s. Perhaps the most disastrous example of the power of implied guarantees is Fannie Mae and Freddie Mac, privately-owned governmentsponsored enterprises whose AAA debt rating allowed them to expand their share of the US mortgage Market from 13\% on 1982 to 52\% in 2007. As Exhibit 6 shows, their collapse in the debt crisis wiped-out the equity investors but returned $100 \%$ to debt investors as the implicit guarantee became explicit and the GSEs came under government conservatorship, effectively doubling the national debt as it stood at the time.

Bailouts, whether explicit or implicit, create a potentially important public subsidy for major financial firms - the mere prospect of a government rescue can lower their cost of capital and assure clients that they will be around. This in turn can help them gain market share and crowd-out less systemic competitors, using an unpriced resource that may swamp the basic economics of financial intermediation. The cycle is clear systemic means implicit government subsidies, which in turn make beneficiary firms more systemic and encourages moral hazard.

That such support can extend well beyond classic financial intermediaries even in cases where private-sector remedies are available was illustrated in the 1998 collapse of Long-term Capital Management, Inc., brokered by the Federal Reserve 
(despite the fact that a credible private restructuring offer was on the table from Berkshire Hathaway, Goldman Sachs and AIG) on the basis that the firm's failure could cause unpredictable damage to the global financial system. A decade later, the same argument was made by JP Morgan about the global copper market and one of its thendominant traders, Sumitomo, when the bank suggested that the 1996 collapse of the world copper market could have serious systemic effects, given major banks' exposures in highly complex structured credits to the copper industry. A few years later, there were discussions about the systemic effects of the collapse of Enron in 2001, WorldCom in 2002 and others.

Much of the time such arguments are self-serving nonsense, but in the political environment during crisis conditions, TBTF guarantees can help throw a safety net broad enough to limit damage to shareholders and unsecured creditors of exposed banks and other financial firms, or sponsor mergers or other rescues that leave them in far better shape than in bankruptcy or liquidation (and paradoxically create even more systemic financial firms in the process). Central to the whole issue is the problem of moral hazard, since the prospect of bailouts can be thought of giving large and interconnected financial intermediaries the incentive to increase the risk of their operations in the chase for higher equity returns. Without state assurances, uninsured depositors and other liability holders demand a risk premium, but for a firm that will not be allowed to fail, this premium is no longer necessary. If the safety net is there and shareholders or unsecured creditors expect not to fall through the mesh, why worry?

It is generally accepted that the larger the bank, the more likely it is to benefit from a safety net in times of crisis. Indeed, one empirical study found a significant valuation premium in the very largest of its sample financial firms (those with total assets above $\$ 100$ billion), possibly indicating the impact of implicit systemic guarantees covering very large financial conglomerates. [Schmid and Walter, 2009] The same is true of a smaller financial firm (Bear Stearns in the most recent crisis, for example) that is so interconnected with the global network of financial flows that its failure could bring down the whole network. Surely the massive and necessary bailouts during the 2007-09 financial crisis, covering a broad array of institutions, instruments and markets (see Exhibit 7) distorts the US financial architecture, now and in the future, through support actions sufficient to override many of the underlying economic drivers of the financial sector's structure, conduct and performance.

\section{Benchmarking the Regulatory Options}

As a general proposition, financial intermediaries cannot be allowed to impose politically unacceptable costs on society, either by failing individuals deemed worthy of protection in financial matters or by permitting firm-level failure to contaminate other financial institutions and, ultimately, the system as a whole. Protecting the system from misconduct and instability is in the public interest, and inevitably presents policymakers with difficult choices between financial efficiency and innovation on the one hand, and institutional and systemic safety and stability on the other, together with the assuring 
integrity and sound business conduct in financial dealings. And because the services provided by banks and other financial intermediaries as allocators of capital affect nearly everything else in the economy, regulatory failure quickly becomes a traumatic event with important consequences for the real sector.

The complexity of the financial services industry as a whole and individual financial intermediaries themselves has important and unique implications for the nature and effectiveness of regulation. Markets and institutions tend, perhaps more often than not, to run ahead of the regulators. Regulatory initiatives sometimes have consequences that were not and perhaps could not have been foreseen, as discussed in Section 2 of this paper.

The regulatory dialectic in the financial services sector is both sophisticated and complex, and it often confronts heavily entrenched and politically well-connected players (and runs up against the personal financial interests of some of the brightest minds and biggest egos in business). The more complex the industry, the greater the challenge to sensible regulation, probably nowhere as strikingly as in the case of massive, complex, global financial services conglomerates that may be too hard to manage, too hard to oversee and govern, and almost certainly too hard to monitor and regulate.

\section{The Trade-offs}

In terms of their mandate from the public, regulators must strive to achieve maximum static and dynamic efficiency of the financial system as a whole. That is, they need to ensure both efficiency in financial flows and innovation in financial products and processes, and they need to promote the competitive viability of financial institutions that are subject to regulation. Simultaneously, they must safeguard the (microprudential) stability of key institutions and the (macro-prudential) stability of the financial system as a whole. In addition, they need to ensure what is considered "acceptable" market conduct in order to retain confidence in financial integrity, including the politically sensitive implied social contract between financial institutions and unsophisticated clients (consumer protection).

We have noted that the problem of safety-net design is beset with difficulties such as moral hazard and adverse selection. This becomes especially problematic when products and activities shade into one another, when on-and off-balance sheet activities are involved, and when domestic, foreign and offshore business is conducted by financial firms for which the regulator is responsible. The problem of market conduct is no less difficult, when end- users of the system range across a broad spectrum of financial sophistication from mass-market retail clients to highly sophisticated, interprofessional trading counterparties. All the while, the system has to be sufficiently robust to avoid arbitrage across geographic or functional jurisdictions by firms that can afford the best legal minds and lobbyists that money can buy. 
In short, regulation in the public interest has as its objective the maintenance of a financial system that is safe, sound and equitable - one that is resistant to collapse and avoids contamination of the payments system and credit allocation (and therefore the real economy), is hard to "game," and provides a level playing field for participants without precluding the failure of institutions that are not competitively viable or are poorly managed. A tall order indeed.

More broadly, the regulatory function in finance remains almost entirely a matter of national sovereignty. Yet banks and other financial firms can and do operate across national jurisdictions, and in offshore markets that can help them avoid significant parts of the regulatory net altogether. Regulatory burdens deemed excessive in one country can trigger migration of financial value-added that can significantly shift the gains from one financial center to another, encouraging regulatory laxity. With safety nets and regulation almost entirely a matter of national sovereignty, who is responsible. For example, should firms that operate across national borders be broken-up into networks of national intermediaries so that those who carry the safely net get to do the regulating? What would be gained? What would be lost?

In a highly competitive industry with multiple functional and geographic regulators, is this a race to the bottom? Probably not.

One can think about financial regulation and supervision as imposing a set of "taxes" and "subsidies" on the operations of financial firms exposed to them. [Kane, $1987,2001]$ On the one hand, the imposition of reserve requirements, capital adequacy rules, liquidity requirements, financial disclosure rules, limits on off-balance sheet transactions and the like can be viewed as imposing "taxes" on a financial firm's activities, in the sense that they increase intermediation costs. On the other hand, regulator-supplied deposit insurance, information production and dissemination, and lender of last resort facilities serve to stabilize financial markets, reduce information and transaction inefficiencies, improve liquidity, and lower the risk of systemic failure, thereby supporting the process of financial intermediation. Such functions by regulators can be viewed as implicit "subsidies" ultimately provided by taxpayers.

The difference between these "tax" and "subsidy" elements of regulation and public support can be viewed as the "net regulatory burden" (NRB) faced by particular types of financial firms in any given jurisdiction. All else equal, financial flows tend to migrate toward those regulatory domains where the NRB is lowest. NRB differences can induce financial-intermediation shifts across markets and geographies when the savings realized exceed the transaction, communication, information, and other economic costs of shifting.

It has been argued that a significant driver of global financial disintermediation and the involvement by various types of financial firms, discussed in Section 3, has been due to differences in NRB. As financial firms continuously seek to reduce NRB and can do so at acceptable cost, they will actively seek product innovations or transaction venues that will help achieve this objective. Only two years before the onset 
of the 2007-09 global financial crisis, two major reports - one commissioned by then Treasury Secretary Henry Paulson [Committee on Capital Markets Regulation, 2006] and the other commissioned by McKinsey for officials of the City and State of New York [McKinsey, 2007] - argued for significant US deregulation to avoid losing large parts of wholesale financial intermediation to London and other financial centers based on evidence (much of it seriously flawed) that this migration was already well underway. The "elegant whining" that permeated both reports was somewhat mistimed, coming as it did only months before the roof fell in on the US system, in part attributable to regulatory failures.

In going about their business, regulators continuously face the possibility that "inadequate" regulation will result in costly failures and, alternatively, that "overregulation" will create opportunity costs in the form of financial efficiencies or innovations not achieved, or in the relocation of firms and financial transactions to other regulatory regimes offering lower NRBs. Since any improvements in financial stability can only be measured in terms of damage that did not occur and costs that were successfully avoided, the argumentation surrounding financial regulation is invariably based on "what if" hypotheticals. In effect, regulators are constantly compelled to rethink the balance between financial efficiency and creativity on the one hand, and safety, stability, and suitable market conduct in the financial system on the other. They face the daunting task of designing an "optimum" regulatory and supervisory structure that provides the desired degree of stability at minimum cost to efficiency, innovation, and competitiveness - and to do so in a highly politicized environment in a way that effectively aligns such policies among regulatory authorities functionally and internationally and avoids "fault lines" across regulatory regimes. There are no easy answers. There are only "better" and "worse" solutions as perceived by the constituents to whom the regulators are ultimately accountable.

\section{Regulatory Performance Against Benchmarks}

US financial history shows how difficult it is to strike the right balance in financial regulation. In commercial banking alone, that history records well over 15,000 failures between 1900 and today - 5,000 just during the Great Depression of the 1930s and an annual average of well over 100 some fifty years later during the 1980s (not including massive failures of thrift institutions and the $\$ 150$ billion taxpayer bailout in the Savings \& Loan debacle). Mismanagement or outright fraud have left prominent names like Banco Ambrosiano, BCCl, Bank Bumiputra, Crédit Lyonnais, Barings, Franklin National Bank, Herstatt, Schroder Münchmeyer Hengst, Seafirst, and Continental Illinois among the failed or seriously damaged over the years, plus essentially the entire Japanese banking system and those of Finland, Mexico, Norway, and Sweden in the early 1990s,. The Asian crisis of the late 1990s led to major financial failures in Indonesia, Korea, and Thailand.

The financial crisis that began in 2007 was basically a continuation of this long history of regulatory failure, complete with numerous examples leading up to the crisis of regulatory arbitrage (both functional and geographic), regulatory forbearance and the 
political capture of regulators by the institutions they were supposed to regulate - with enormous costs to the financial system and the economy as financial instability contaminated the real sector.

Most of the regulators on the bridge when the ship hit the iceberg have acknowledged the policy shortcomings that contributed to the disaster, in sharp contrast to the senior managements and boards of the institutions directly involved. Perhaps the most respected and experienced observer of the US financial system, former Federal Reserve Chairman Paul Volcker, noted in a speech in April 2008 that "... today's financial crisis is the culmination, as I count them, of at least five serious breakdowns of systemic significance in the past 25 years - on the average one every five years. Warning enough that something rather basic is amiss.... Simply stated, the bright new financial system - for all its talented participants, for all its rich rewards - has failed the test of the market place... [A] demonstrably fragile financial system that has produced unimaginable wealth for some, while repeatedly risking a cascading breakdown of the system as a whole, needs repair and reform." ${ }^{14}$

Volcker is clearly on-target in terms of financial instability and its costs to society, but even he cannot document the counterfactual: How would the world have turned out - in terms of economic growth and other things people care about - if a bulletproof regulatory system had prevailed for the preceding half century, effectively impeding most of the efficiency and innovation that ultimately contributed to the instability? Would society have been better off? Volcker would surely concede this point, but probably steadfastly maintain that we can do much better going forward.

\section{Conclusions: Should Financial Conglomerates be Broken-up?}

Section 2 of this paper provided an account of the forced breakup of US universal banks in the financial and economic crisis of 1933, coinciding with the transfer of power to the new administration of Franklin D. Roosevelt. There was little time or sympathy for special pleading, influence peddling or legal challenges. The new president was preoccupied with an economic disaster and had little compassion for the banks as his administration turned to a mixed bag of measured to try to break the cycle of economic collapse. The contentious Pecora Hearings, leading up to the Banking Act of 1933, had put the big US universal banks on the defensive and limited their political influence on the rules of the game. It proved to be a window of opportunity in which the public interest as then perceived was clearly paramount, and Congress did what it felt it had to do, for better or worse. As discussed, the result had a profound impact on the structure of US and global finance for well over half a century.

Emergence from the latest crisis provides a window of opportunity to once again change the rules in the direction the public interest, although it is closing fast. Most

\footnotetext{
${ }^{14}$ Paul A. Volcker, remarks at a meeting of the Economic Club of New York, 28 April 2008, transcript at http://econclubny.org/files/Transcript_Volcker_April_2008.pdf
} 
legislative hearings on the issues have been pale imitations of the 1933 Pecora Hearings, often involving political grandstanding and photo-ops for the political by the people's representatives - themselves major recipients of political contributions from the financial services executives testifying before them. In the background, their "seventh line of business" lobbying shops were in overdrive to maintain public subsidies awarded during the height of the crisis and preempt regulatory change deemed against their interests.

The chemistry of special interest politics of financial reform has been likened to the kind of third-world "crony capitalism" the US has consistently lectured others about which assures a green light for financial institutions to go back to business as usual as quickly as possible even as they continue to benefit from taxpayer subsidies. [Johnson, 2009] Defeatists have argued that it will take an even more devastating crisis, one that engulfs politics (notably campaign finance reform) as well as finance and economics, to trigger a Pecora-like process and lead to meaningful reforms.

\section{Calibrating the Options}

From the perspective of the public interest alone, Section 3 of this paper has suggested four key benchmarks against which financial systems should be calibrated. These can be summarized as follows:

1. Static efficiency. The metrics include the weighted mean spread between what ultimate savers (predominantly households) receive and what ultimate users of capital (households, nonfinancial businesses and governments) have to pay. That spread is heavily influenced by some composite of operating costs, regulatory costs, and intermediation losses.

2. Dynamic efficiency. Here the metrics are less transparent, and include product and process innovation and technology change in financial intermediation and the role of the financial system in promoting economic growth by continually allocating and denying capital to competing uses in the production function that drives the real economy.

3. Stability. The financial system itself should be sufficiently robust to withstand shocks that will inevitably emanate from the real sector from time to time, and the financial sector should be resistant producing shocks of its own, which inevitably spill over into the real sector of the economy.

4. Competitiveness. In a macro sense, the financial sector is an industry like any other, and generates income, employment and international trade in services. Countries compete vigorously to maintain financial centers that add value in this regard. New York and London are the dominant global wholesale hubs, arch-rivals and constantly under competitive pressure from insurgent financial centers, particularly as the contours of financial flows shift geographically. Key metrics include share of new debt and equity issues, secondary market trading volumes, exchange-traded and OTC derivatives volumes, assets under management, and M\&A deals advised. 
As outlined in Section 4 of this paper, these benchmarks may well conflict with each other and involve tradeoffs that are often hard to identify and measure. Nevertheless, options for financial reform - and particularly line-of-business or geographic constraints - that are in the public interest should be calibrated largely against these benchmarks. The results can usually be assessed only after some time has passed. And even then, they are invariably controversial based on counterfactuals that will be put forward.

\section{Evaluating the Alternatives}

There are at least four alternatives for regulating the scope of business of financial intermediaries going forward.

1. Modified laissez faire. The first option is essentially maintaining the status quo (the Gramm-Leach-Bliley rules in the US and universal banking rules in other countries), and allowing banks or bank holding companies to engage in all forms of financial intermediation and principal investing worldwide, subject to certain firewalls and other safeguards. These safeguards would be duly modified to deal with systemic risk and incorporate the lessons of the financial crisis of 2007-09. This option is already in train in the US, and major regulators elsewhere have recommitted themselves to the universal banking or financial conglomerate model, i.e., that bigger and broader are better.

In June 2009 the Obama administration proposed a laundry-list of financial reforms that will be subject to debate for some time to come, most of them eminently sensible but vulnerable to being dissected and defanged in the political-regulatory process. [Department of the Treasury, 2009] Organizationally, there is a Financial Services Oversight Council in the White House, chaired by the Secretary of the Treasury and comprising the seven key financial regulators. Since the plan contains no major changes in the regulatory structure except a new consumer finance agency, a key role of the Council will be to deal with the inevitable turf battles and regulatory arbitrage that is bound to persist.

The plan foresees the identification of systemic financial intermediaries - so-called "Tier 1 financial holding companies (FHCs)." Criteria for classification as a Tier 1 firm include the impact a firm's failure would have on the financial system and the economy; the firm's combination of size, leverage (including off-balance sheet exposures), and degree of reliance on short-term funding; and the firm's criticality as a source of credit for households, businesses, and state and local governments and as a source of liquidity for the financial system, especially under stressed economic conditions. A systemic risk regulator is foreseen that has sufficient discretion to reach beyond financial holding companies in order to adapt to inevitable innovations in financial activity and in the organizational structure of financial firms, and to prevent regulatory arbitrage. 
Damaged Tier $1 \mathrm{FHCs}$ will be subject to prompt corrective action (PCA) based on a decline in their capital ratios below regulatory minimums, effectively extending the mostly successful experience of the FDIC as provided in the 1991 Federal Deposit Insurance Corporation Improvement Act. Each Tier 1 financial holding company will have to maintain an actionable plan to wind-down the firm in case of severe financial distress, orderly resolution that was sorely missed during the crisis

Tier 1 financial firms will be subject to more exacting prudential supervision and more stringent capital and liquidity standards than non-systemic firms. The plan also refers to more stringent "activity standards." Two sections of the Treasury plan cover this issue [US Treasury, 2009] as follows:

A. Tier 1 FHCs that do not control insured depository institutions should be subject to the full range of prudential regulations and supervisory guidance applicable to bank holding companies (BHCs). In addition, the long-standing wall between banking and commerce - which has served our economy well - should be extended to apply to this new class of financial firm. Accordingly, each Tier $1 \mathrm{FHC}$ also should be required to comply with the nonfinancial activity restrictions of the Bank Holding Company Act of 1956, regardless of whether it controls an insured depository institution....A Tier $1 \mathrm{FHC}$ that has not been previously subject to the [Bank Holding Company Act] should be given five years to conform to the existing activity restrictions imposed on FHCs by the BHC Act.

B. [Provisions in the] Federal Reserve Act are designed to protect a depository institution from suffering losses in its transactions with affiliates. These provisions also limit the ability of a depository institution to transfer to its affiliates the subsidy arising from the institution's access to the federal safety net, which includes FDIC deposit insurance, access to Federal Reserve liquidity, and access to Federal Reserve payment systems....The recent financial crisis has highlighted, more clearly than ever, the value of the federal subsidy associated with the banking charter, as well as the related value to a consolidated financial firm of owning a bank. Although the existing set of firewalls... are strong, the framework can and should be strengthened further. Specifically, we propose that regulators should place more effective constraints on the ability of banks to engage in over-the-counter (OTC) derivatives and securities financing transactions with affiliates [and] covered transactions between banks and their affiliates should be required to be fully collateralized throughout the life of the transactions. Moreover, the existing federal restrictions on transactions between banks and affiliates should be applied to transactions between a bank and all private investment vehicles sponsored or advised by the bank. The Federal Reserve's discretion to provide exemptions from the bank/affiliate firewalls also should be limited....Finally, the Federal Reserve and the federal banking agencies should tighten the supervision and regulation of potential conflicts of interest generated by the affiliation of banks and other financial firms, such as proprietary trading units and hedge funds. 
The key dimensions of the Obama plan that could affect the structure of financial intermediaries thus involve (a) mandating a systemic risk regulator, (b) "pricing" implicit public subsidies to systemic financial firms using capital and liquidity requirements, and (c) limiting the engagement of systemic financial firms in certain financial activities. Whereas the 1930s US reforms were truly revolutionary and in many ways visionary, the government's 2009 reforms are cautious and incremental, mainly patching holes in a failed system and establishing early-warning and corrective action which hopefully will catch the next big crisis in time to prevent system-wide damage.

Will they succeed? Much depends on how well the new systemic risk regulator presumably the Federal Reserve - is able to do its job. Is it really likely that systemic institutions that have shown themselves to be too big and complex to manage and too big, complex and interconnected to regulate by the existing regulatory structure will be rendered failsafe under the evolutionary new regime. The ease with which the investment banking industry was able to increase leverage ratios in 2004, or the commercial banking industry in $\mathbf{2 0 0 9}$ was able to undermine hard-fought progress on fair value accounting and permit bank manipulate earnings does not augur well for future regulatory capture. Certainly much talent in the years ahead will be devoted to avoidance, evasion, obfuscation and financial innovation with little or no commercial purpose.

Critics of the Federal Reserve as the lead regulator of systemic financial firms argue that its track record in the run-up to the most recent crisis proved to be very poor indeed - but not necessarily worse than the combined efforts of the Bank of England and the Financial Services Authority in the UK, or the European Central Bank and the gaggle of national regulators in continental Europe. Excessive pessimism is certainly premature, but the Fed's increased politicization is a virtual certainty going forward, as its mandate extends further from monetary policy into politically sensitive macroprudential and microprudential domains. Together with the Treasury, it's damage control efforts in the crisis broke all precedents. Will this become the norm? Certainly any hijacking of monetary policy to serve these new mandates is hardly likely to be in the public interest.

On the other hand, pricing systemic risk using a combination of capital and liquidity requirements and the cost of more intense regulatory supervision has considerable promise. Effectively, these are "taxes" intended to internalize the negative externalities created by firms that produce systemic risk. Like pollution control, this previously unpriced or underpriced resource will henceforth be priced, and (assuming they cannot successfully undermine the policy) systemic financial firms will then have the opportunity to react. If boards and managements are doing their jobs, they will carefully reexamine the costs and benefits of remaining a massive financial conglomerate, for example, and find ways of escaping the newly imposed taxes - which will have to be agreed globally to prevent regulatory arbitrage.

Skeptics, of course, will point to demonstrated weaknesses among financial institutions' boards (including extreme complexity that prevents boards to know what they need to know), the virtual absence of hostile takeovers in financial services (i.e., 
the absence of a well functioning market for corporate control in the financial sector), and the willingness of boards to live with the large discounts that seem to characterize financial conglomerates. With improved corporate governance and successful resistance to regulatory capture through a money-driven political process, the Obama approach may trigger much needed restructuring carried out by the firms themselves, including breakup of financial conglomerates, a larger cohort of nonsystemic and easierto regulate specialist firms, and shifting to investors the opportunity to create more efficient portfolios of exposures to equity and debt investments in financial intermediaries.

2. Geographic Fragmentation - Even supporters of the Obama approach are concerned with global coordination and avoidance of competitive distortions, impeding globalization of finance that has contributed significantly to world economic growth. Observers point to the fact that national governments such as the UK, Switzerland, Japan, France and the US ultimately support the safety net covering financial conglomerates and other systemic firms based in their jurisdictions. In the case of large international firms based in small countries, the spillover from systemic risk of institutional failure to sovereign risk is obvious. Such countries therefore have an additional incentive to apply serious safety and soundness policies on their financial firms, as in the Obama plan, and then let the firms decide whether they should change their business models to avoid the costs. This incentive also suggests that most of the world's home-countries of systemic financial firms would have a great incentive for the kind of international regulatory harmonization and coordination needed to make it work.

Skeptics argue that most countries are so wedded to the universal banking financial conglomerates model that they are unlikely to go along with the tougher regulatory architecture that may result. Moreover, the length of time it took to achieve the Basle accords on capital adequacy (which turned out to be necessary but not sufficient under stress) does not augur well for effective globally coordinated regulatory reforms before the next crisis appears. An alternative that has been proposed is to force global systemic institutions to run their non-domestic operations as separately incorporated subsidiaries of the parent firm and regulated principally by the host countries. Host regulators, it is argued, are closer to the action and ultimately would have to carry the safety net, in effect ring-fencing local operations from support obligations on the part of home countries. Understandably, this argument has been received most enthusiastically in small countries home to big global financial firms.

There are of course telling counter-arguments. [Ackermann, 2009] The consequences for market-based global allocation of capital and risk would likely be debilitating, and new mechanisms would have to be found to preserve as much efficiency and innovation as possible in cross-border financial flows. Like protectionism in international trade, the costs of financial fragmentation could be enormous, although these costs are often broadly dispersed and hard to measure. On the positive side, the threat of financial fragmentation has provided a fear factor among politically powerful systemic firms, possibly undermining their resistance to other, less damaging regulatory options. 
3. Reinstate a Modified Version of Glass-Steagall - The argument is that key activities of investment banks are incompatible with the special character of commercial banking, namely operating the payments system, taking deposits and making commercial loans, and serving as the transmission belt for monetary policy. These activities include underwriting and dealing in corporate debt and equities, asset-backed debt and certain other securities, derivatives of such securities including credit default swaps, principal investing and managing in-house hedge funds. These activities are also demed incompatible with access to Federal Reserve discount facilities, debt guarantees and other sources of government support intended to safeguard the public utility attributes of commercial banking.

Under this option, the legacy investment banks that converted to bank holding companies in the crisis to gain full access to the government safety net (Goldman Sachs and Morgan Stanley) would revert to broker-dealer status and would be functionally regulated as such alongside oversight by a systemic risk regulator. The investment banking divisions of commercial banks would be sold, floated or spun-off to shareholders, and similarly regulated. Investment banking divisions of foreign financial conglomerates would have to be similarly divested or operate in the US as separately capitalized subsidiaries.

The discussion in Section 2 of this paper has suggested that the Glass-Steagall constraints of 1933 may in fact have performed relatively well - when benchmarked against all four of the foregoing criteria - for over half a century. The epic battle between bank-based and capital-market based finance, domestically and internationally, assured static and dynamic efficiency pressure on all financial intermediaries, the system maintained basic stability in the face of major macro shocks and changing monetary standards. During this period, New York became the leading global center of finance, with London (benefiting from natural advantages such as time-zone overlaps and policy advantages such as light regulation and a thriving offshore market) as its only serious rival.

All of the continental financial centers, dominated as they were by universal banks, dropped by the wayside as their own investment banking units joined their chief global wholesale rivals in London and New York. Meantime, investment banks gravitated to an integrated full-service model, complemented by boutiques, and thrived without access to central bank liquidity facilities or public bailouts in the case of failures like Barings in London or Peregrine Securities in Hong Kong. The same was true of buy-side specialists in the mutual fund business (e.g., Fidelity and Vanguard), pension funds (e.g., TIAA-CREF in the US and Hermes in the UK) and hedge funds (e.g., Soros and Tiger), although admittedly LTCM was a close call. Buy-side specialists help prevent the perennial problem of multiline firms trying to represent buyers and sellers simultaneously and the intractable conflicts of interest that result from them.

The survival and even prosperity of financial specialists in the presence of government supported and subsidized bank holding companies suggests that a modern version of Glass-Steagall would not be ruinous when benchmarked against the four 
aforementioned criteria. M\&A boutiques ranging from Perella Weinberg to Lazard Frères seem to be thriving on the basis of dispassionate corporate advice. So are midsize investment banks like Jeffries \& Co., which do a viable mid-market business and make a point foregoing government support as against their conglomerate rivals. Almost certainly A.G. Edwards would have done likewise if it had not disappeared into the Bank of America conglomerate. In asset management and private equity, the dominant players like BlackRock, Vanguard, TPC and Carlyle have performed well against competing units of financial conglomerates, and in some cases have turned from clients to competitors in corporate finance. All of this is only anecdotal evidence, but it suggests that a powerful non-bank financial intermediation industry would quickly emerge following Glass-Steagall type re-regulation, one populated by relatively transparent firms that lend themselves to relatively straightforward oversight by functional regulators in tandem with a systemic risk regulator.

3. Functional carve-outs and size constraints. A less draconian approach to reinstatement of activity separation along the lines of Glass-Steagall involves recognition that some types of financial activities should not be allowed within multifunctional financial firms deemed to be systemic and having powerful public utility characteristics. Among these activities are:

- Management of in-house hedge funds.

- Creating off balance sheet affiliates having no commercial purpose.

- Running large proprietary trading positions in cash securities and derivatives.

- Acting as principal investors in nonfinancial activities such as real estate and private equity.

Financial conglomerates will argue that such carve-outs will limit synergies that are essential to their business models, despite general lack of evidence that such synergies actually exist, as discussed in Section 3 of this paper. Indeed, it is likely that a host of nonbank financial firms will step up to conduct those activities that contribute static or dynamic gains without risking systemic consequences as long as they appropriately regulated along functional lines with systemic risk oversight.

An alternative to carve-outs is to limit the size of financial conglomerates that incorporate commercial banking units, so that they are forced to become non-systemic. Metrics to achieve this could include market share caps, deposit or asset ceilings, and the like. This would not involve activity prohibitions, but size-constrained financial conglomerates would soon lose critical mass in specific areas of engagement, and presumably would try to focus on the most profitable ones and divest others. This could be a more market-aligned and elegant solution than specific activity carve-outs. Given murky evidence on the relationships between firm size and efficiency, stability and competitiveness, size constraints may have some merit. Paradoxically, or course, the general response of policymakers to the crisis (except for Lehman Brothers) is to make financial Goliaths even bigger and even more systemic. 
All things considered the most defensible approach given the facts on the ground and assuming it can be carried out in a disciplined, consistent, internationally coordinated and sustained manner with a firm eye to the public interest - is the first of these alternatives. By creating a shadow price for systemic risk universal banks and financial conglomerates will draw their own strategic conclusions in the context of the microeconomics and industrial organization of global wholesale financial intermediation. But these are big assumptions. Those who have become incurably cynical about politics and regulatory capture might think about advocating specific activity carve-outs as a second best alternative. Either option stands a reasonable chance of preventing the next "big one," which surely would force a hard-return to Glass-Steagall with few regrets.

\section{References}

Aachrya, Viral and Matthew Richardson (eds), 2009. Restoring financial stability. New York: John Wiley \& Sons.

Ackermann, Josef. 2009. Smaller banks will not make us safer. Financial Times, 30 July, p. 9. - http://www.ft.com/cms/s/0/9aef3d00-7c6d-11de-a7bf-00144feabdc0.html

Berger, Philip G., Ofek, Eli, 1995. Diversification's effect on firm value. Journal of Financial Economics 37, 39-65.

Bodnar, Gordan M., Tang, Charles, Weintrop, Joseph, 1999. Both sides of corporate diversification: The value impacts of geographic and industrial diversification. Working Paper, Johns Hopkins University.

Campa, Jose M., Kedia, Simi, 2002. Explaining the diversification discount. Journal of Finance 57, 1731-1762.

Committee on Capital Markets Regulation, 2006. Interim report of the Committee on Capital Markets Regulation (The Paulson Report). Washington, D.C.: US Government Printing Office.

DeLong, Gayle, 2001a. Stockholder gains from focusing versus diversifying bank mergers. Journal of Financial Economics 59, 221-252.

DeLong, Gayle, 2001b. Focusing versus diversifying bank mergers: Analysis of market reaction and long-term performance. Working Paper, CUNY.

Denis, David J., Denis, Diane K., Yost, Keven, 2002. Global diversification, industrial diversification, and firm value. Journal of Finance 57, 1951-1979. 
Fauver, Larry, Houston. Joel F., Naranjo, Andy, 2004. Cross-country evidence on the value of corporate industrial and international diversification. Journal of Corporate Finance 10, 729-752.

Gande, Amar, Puri, Manju, Saunders, Anthony and Walter, Ingo, 1997. Bank underwriting of debt securities: Modern evidence, Review of Financial Studies, 1997, 10(4), 1175-1202.

Gande, Amar, Puri, Manju and Saunders, Anthony, 1999. Bank entry, competition and the market for corporate securities underwriting, with A. Gande and Anthony Saunders, Journal of Financial Economics, 54(2), 165-195.

Houston, Joel, Ryngaert, Michael, 1994. The overall gains from large bank mergers. Journal of Banking and Finance 18, 1155-1176.

Johnson, Simon, 2009. The quiet coup. Atlantic Monthly, May.

Kane, Edward J. 1987. Competitive financial reregulation: An international perspective. In R. Portes and A. Swoboda (eds.) Threats to international financial stability. Cambridge: Cambridge University Press.

Kane, Edward J. 2001. Relevance and need for international regulatory standards. Brookings-Wharton papers on financial services. 87-115.

Laeven, Luc, Levine, Ross, 2007. Is there a diversification discount in financial conglomerates? Journal of Financial Economics 85, 331-367.

McKinsey \& Co. 2008. Sustaining New York's and the US' global financial services leadership. Report commissioned by Mayor Michael Bloomberg and Senator Charles Schumer. Mayor's Office of the City of New York. Available at http://www.nyc.gov/html/om/pdf/ny_report_final.pdf

Puri, Manju, 1994 The long-term default performance of bank underwritten security issues, Journal of Banking and Finance, 18(2), 397-418.

Puri, Manju, 1996 Commercial banks in investment banking: Conflict of interest or certification role? Journal of Financial Economics, 40(3), 373-401.

Puri, Manju, 1999. Commercial banks as underwriters: Implications for the going public process, Journal of Financial Economics, 54(2), 133-163.

Saunders, Anthony and Ingo Walter, 1994. Universal banking in the United States. New York: Oxford University Press, 1994.

Schmid, Markus M., Walter, Ingo, 2008. Do financial conglomerates create or destroy economic value? Journal of Financial Intermediation, forthcoming. 
US Department of the Treasury, 2009. Bank regulatory reform. Rebuilding financial supervision and regulation. Washington, D.C. US Government Printing Office.

Walter, Ingo, 2004. Mergers and acquisitions in banking and finance. Oxford University Press, New York. 
Exhibit 1

\begin{tabular}{|c|c|c|c|c|c|c|c|c|}
\hline \multirow[b]{3}{*}{ Firm } & \multirow[b]{3}{*}{$\begin{array}{l}\text { Rank } \\
2005\end{array}$} & \multirow{2}{*}{\multicolumn{5}{|c|}{$\begin{array}{c}\text { Global Investment Banking Market Shares (\$000 millions) } \\
\text { Full Credit to Book Running Managers Only }\end{array}$}} & \multirow[b]{3}{*}{$\begin{array}{c}\text { MTNs } \\
\text { Arranged }\end{array}$} & \multirow[b]{3}{*}{ Total } \\
\hline & & & & & & & & \\
\hline & & $\begin{array}{l}\text { Rank } \\
2004\end{array}$ & $\begin{array}{l}\text { Syndicated } \\
\text { Bank Loans }\end{array}$ & $\begin{array}{c}\text { Global } \\
\text { Debt }\end{array}$ & $\begin{array}{l}\text { Global } \\
\text { Equity }\end{array}$ & $\begin{array}{c}\text { M8A } \\
\text { Advisory }\end{array}$ & & \\
\hline JP Morgan & 1 & 1 & $572,877.4$ & $369,575.7$ & $29,018.0$ & 717.494 .6 & & $1,688.965 .7$ \\
\hline Citigroup & 2 & 2 & $490,732.6$ & $471,013.1$ & $43,605.0$ & $584,427.4$ & $1,928.5^{\prime}$ & $1,591,706.6$ \\
\hline Goldman Sachs \& Co & 3 & 3 & $74,709.3$ & $239,610.2$ & $36,627.4$ & $920,352.3$ & & $1,271,299.2$ \\
\hline Morgan Stanley & 4 & 4 & $46,878.9$ & $284,660.2$ & $35,681.8$ & $788,784.0$ & & $1,156,0049$ \\
\hline Merrill Lynch \& Co Inc & 5 & 5 & $41,377.7$ & $262,933.3$ & $54,126.7$ & $648,181.4$ & $100.0^{\prime}$ & $1,006,719.1$ \\
\hline Deutsche Bank AG & 6 & 6 & 147,3489 & 376,7930 & $14,637.2$ & $393,791.9$ & & $932,571.0$ \\
\hline Lehman Brothers & 7 & 7 & $43,997.6$ & $361,544.3$ & $26,751.6$ & 459,4620 & $8,000.0^{\prime}$ & $899,755.5$ \\
\hline UBS & 8 & 10 & $36,082.1$ & $258,347.4$ & $29,338.1$ & $525,891.0$ & & $849,658.6$ \\
\hline Banc of America Secunties LLC & 9 & 8 & $344,247.9$ & $245,658.2$ & $9,296.4$ & $169,489.5$ & $17,427.0^{\prime}$ & $786,121.0$ \\
\hline Credit Suisse & 10 & 9 & 74,4263 & $296,744.5$ & 42,8902 & $325,636.6$ & & $740,637.6$ \\
\hline BNP Paribas SA & 11 & 14 & $152,242.1$ & $131,573.6$ & $2,739.3$ & $199,789.5$ & & $4 \otimes 6,3445$ \\
\hline Royal Bank of Scotland Group & 12 & 15 & 173,0382 & $260,176.7$ & & & & 433,2149 \\
\hline Barclays Capital & 13 & 12 & $161,987.1$ & $259,414,4$ & $1,022.6$ & & & $422,424.1$ \\
\hline Bear Stearns \& Co Inc & 14 & 13 & $9,418.8$ & $203,623.8$ & $5,700.7$ & $178,183.7$ & & $397,007.0$ \\
\hline Lazard & 15 & 17 & & & & $356,887.7$ & & $336,887.7$ \\
\hline HSBC Holdings PLC & 16 & 18 & $79,847.2$ & $166,391.0$ & $5,667.4$ & $61,931.4$ & & $313,837.0$ \\
\hline ABN AMRO & 17 & 11 & $93,793.8$ & $123,720.7$ & $5,901.9$ & $85,006.3$ & & 306,4227 \\
\hline Rothschild & 18 & 16 & & & & $250,826.8$ & & $250,826.8$ \\
\hline Industry Total & & & $4,008,838.4$ & $5,469,617.1$ & 466.284 .1 & $3.224,104.1$ & $119,693.4$ & 13.288 .537 .1 \\
\hline
\end{tabular}

Exhibit 2

Citigroup Share Price Since the Merger

(6 April 1998 - Present, Compared to JP Morgan and S\&P 500 Index)

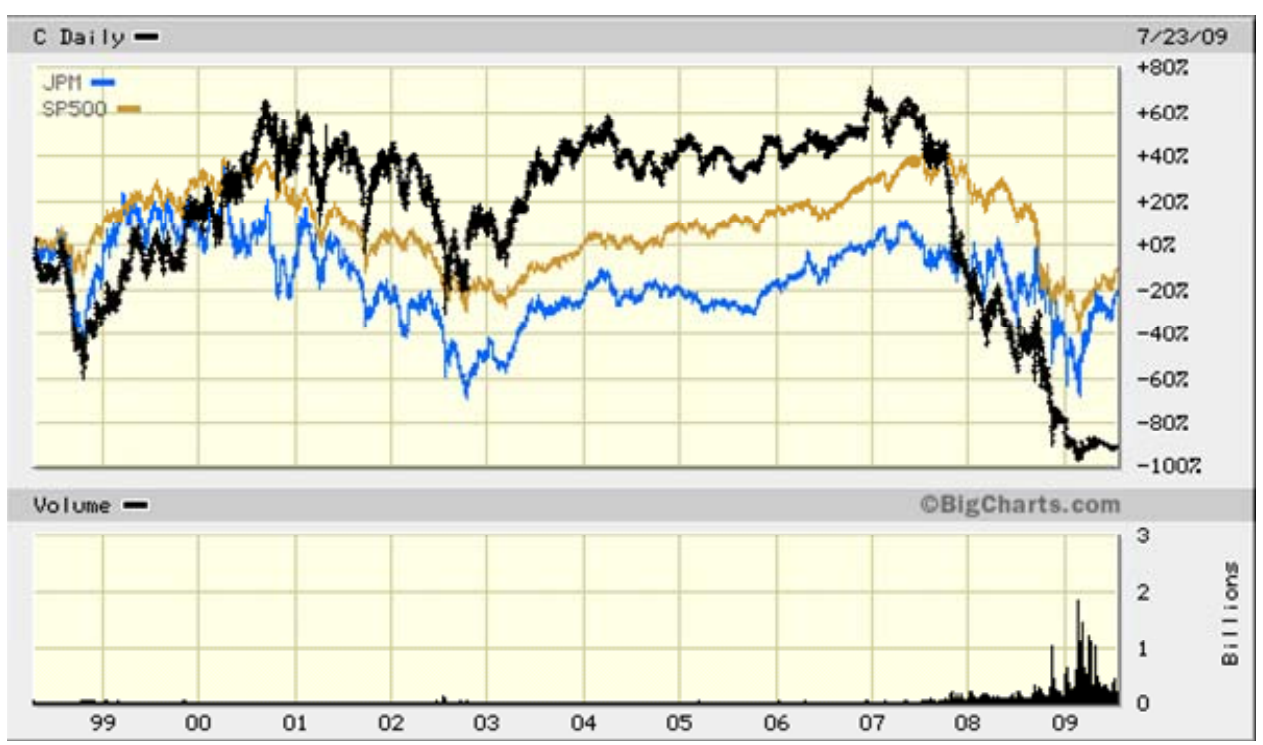

Source: http://bigcharts.marketwatch.com/advchart/frames/frames.asp?symb=\&time=\&freq= 
Exhibit 3

Strategic Opportunity Set Facing Financial Conglomerates

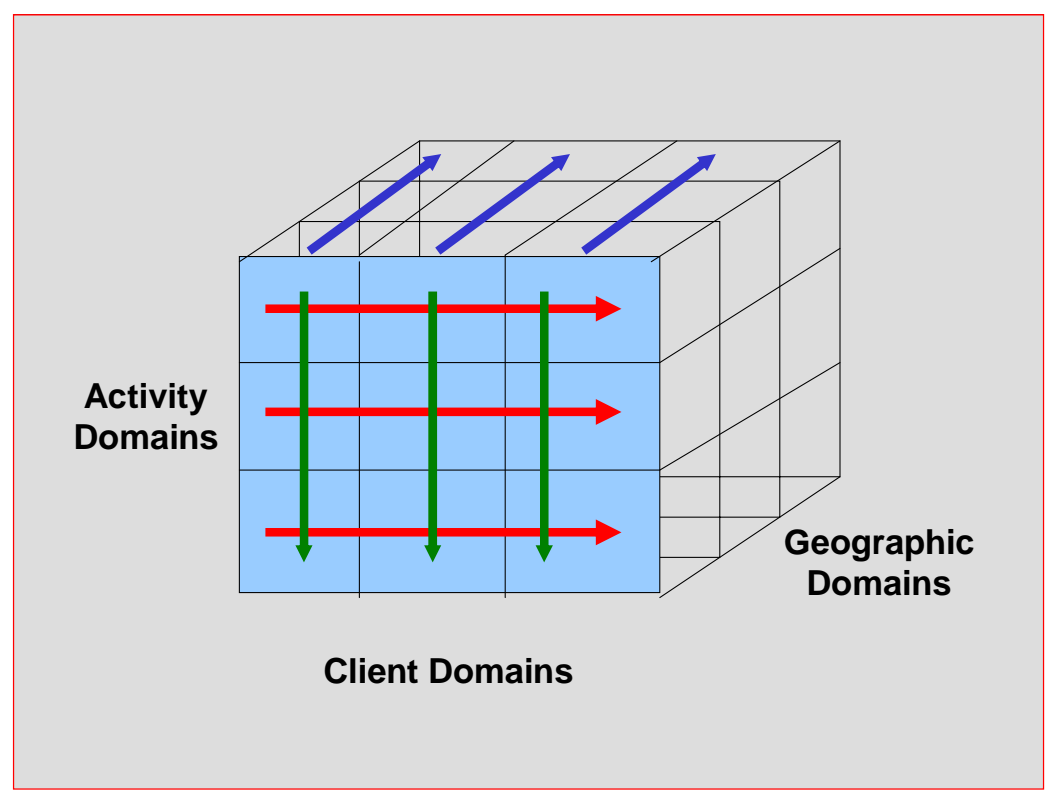

Source: Ingo Walter, Mergers and Acquisitions in Banking and Finance (New York: Oxford University Press, 2004), Chapter 3.

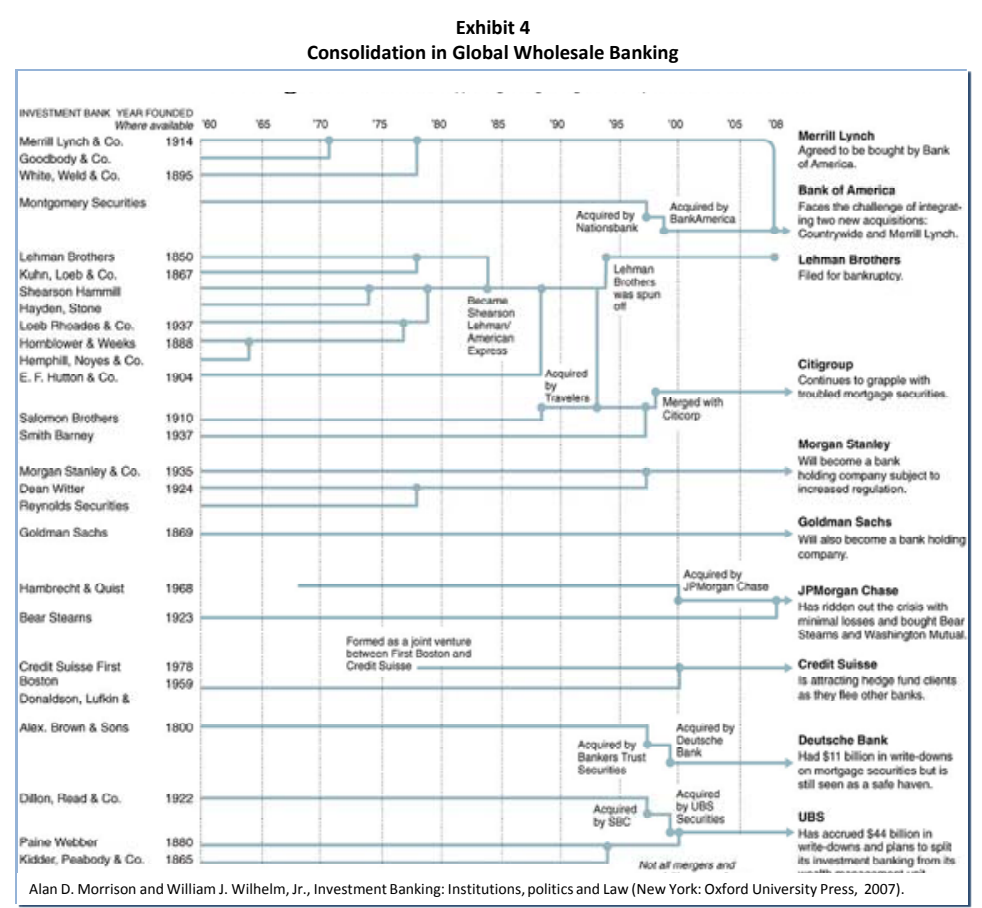


Exhibit 5

Top-10 Global Wholesale Banking Firms - Gross Revenues First-Half 2009

$\begin{array}{lrrrrrr}\text { Bank } & \text { DCM } & \text { ECM } & \text { Loans } & \text { M\&A } & \text { Total } & \text { Share } \\ & & & & & & \\ \text { JPMorgan } & 764 & 1,294 & 121 & 337 & 2,516 & 18.8 \\ \text { BAC-ML } & 648 & 584 & 594 & 339 & 2,165 & 16.2 \\ \text { Goldman Sachs } & 417 & 880 & 29 & 458 & 1,784 & 13.3 \\ \text { Citigroup } & 601 & 474 & 116 & 361 & 1,552 & 11.6 \\ \text { UBS } & 319 & 503 & 35 & 425 & 1,282 & 9.6 \\ \text { Deutsche Bank } & 465 & 411 & 68 & 208 & 1,152 & 8.6 \\ \text { Credit Suisse } & 425 & 474 & 19 & 203 & 1,121 & 8.4 \\ \text { Barclays Capital } & 558 & 226 & 42 & 99 & 925 & 6.9 \\ \text { Morgan Stanley } & 405 & 749 & 7 & 365 & 780 & 5.8 \\ \text { RBS } & 408 & 229 & 68 & 0 & 708 & 5.2\end{array}$

$\mathrm{HHI}=0<1,276.3<10,000$

Source: Dealogic, July 2009

Exhibit 6

Fannie Mae and Freddie Mac Share Prices, 1989-2009

(Compared to S\&P 500 Index)

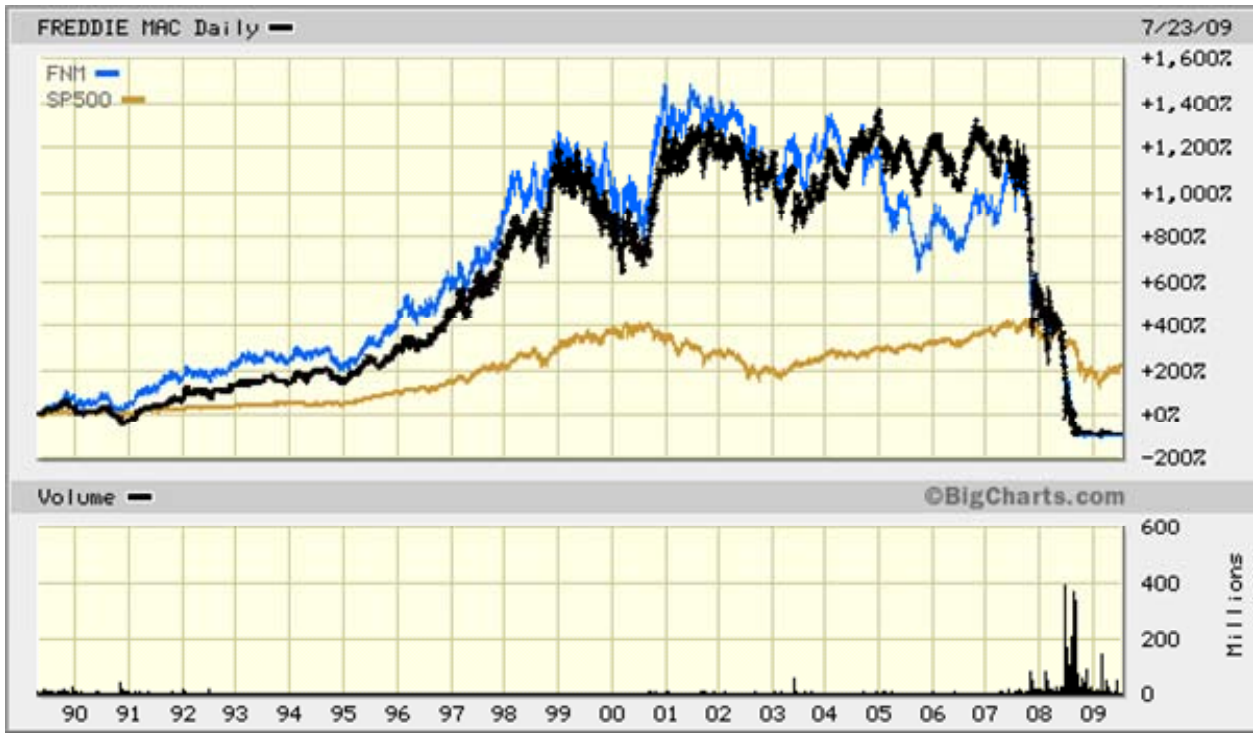

Source: http://bigcharts.marketwatch.com/advchart/frames/frames.asp?symb=\&time=\&freq= 
Exhibit 7

TARP-plus: US Government Bailout Commitments as of 10 February 2009

Beyond the $\$ 700$ billion bailout known as TARP, which has been used to prop up banks and car companies, the government has created aj array of other programs to provide support to the struggling financial system. Through Feb. 10, the govermment has made commitments of nearly $\$ 8.8$ trillion and spent $\$ 2$ trillion. Here is an overview, organized by the role the government has assumed in each case.

\begin{tabular}{|c|c|c|}
\hline \multirow{2}{*}{ 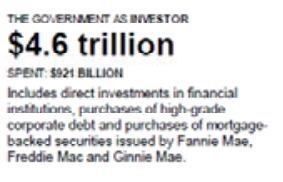 } & $\begin{array}{l}\text { Commercial paper } \\
\text { The Federal Reserve has beconwe the buyer of last resort in the } \$ 1.6 \text { trillon } \\
\text { commercial paper marke. }\end{array}$ & $\begin{array}{r}\text { Committed: \$1.6 trillion } \\
\text { Spent \$257 bifion }\end{array}$ \\
\hline & $\begin{array}{l}\text { Public-private investment fund } \\
\text { This fund. which is not operational yet. will seek private investors and use a } \\
\text { combination of private and public money to buy nonperforming assets from banks. }\end{array}$ & $\begin{array}{l}\$ 1.0 \text { trillion } \\
\text { so bilion }\end{array}$ \\
\hline Freddie Mac and Ginnie Mae. & 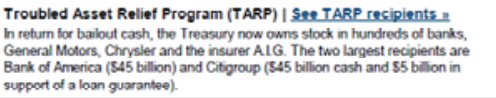 & $\begin{array}{l}\$ 700 \text { billion } \\
\$ 510 \text { billion }\end{array}$ \\
\hline \multirow{2}{*}{ 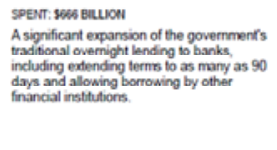 } & $\begin{array}{l}\text { Federal Home Loan Bank securities } \\
\text { The Treasury and the Federal Reseren have begun buring debt and motigage- } \\
\text { backed secunties from Famnie Mae, Fredde Mac and Ginnie Mae. }\end{array}$ & $\begin{array}{l}\$ 600 \text { billion } \\
\$ 212 \text { bllion }\end{array}$ \\
\hline & 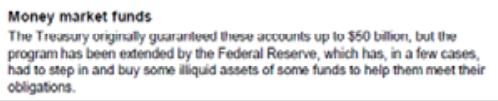 & $\begin{array}{l}\$ 600 \text { billion } \\
\$ 17 \text { bllion }\end{array}$ \\
\hline \multirow{3}{*}{ 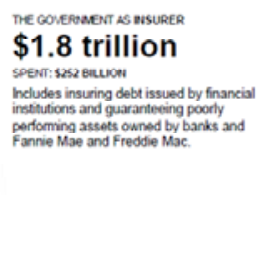 } & 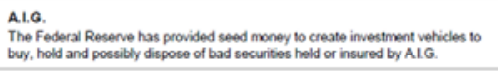 & $\begin{array}{l}\$ 53 \text { billion } \\
\$ 44 \text { bllon }\end{array}$ \\
\hline & $\begin{array}{l}\text { Bear stearns } \\
\text { The Federal Resenve bought distressed assets from Bear Stearns to facilitate its } \\
\text { sale to JPMorgan Chase. }\end{array}$ & $\begin{array}{l}\$ 29 \text { billion } \\
\$ 29 \text { bllion }\end{array}$ \\
\hline & 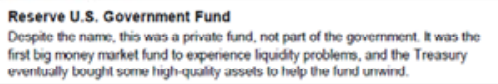 & $\begin{array}{l}\$ 4 \text { billion } \\
\text { s4 bllion }\end{array}$ \\
\hline
\end{tabular}

